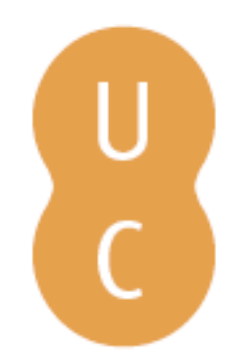

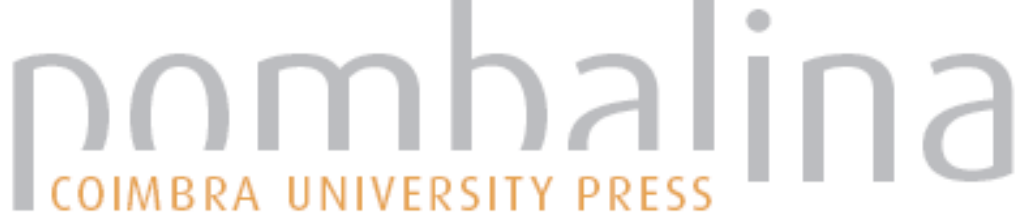

\section{Eudoro de Sousa e a Mitologia}

\author{
Autor(es): $\quad$ Ferrer, Diogo
}

Publicado por: Imprensa da Universidade de Coimbra

URL

persistente: $\quad$ URI:http://hdl.handle.net/10316.2/37038

DOI: $\quad$ DOI:http://dx.doi.org/10.14195/978-989-26-1043-6_3

Accessed : $\quad$ 26-Apr-2023 06:50:00

A navegação consulta e descarregamento dos títulos inseridos nas Bibliotecas Digitais UC Digitalis, UC Pombalina e UC Impactum, pressupõem a aceitação plena e sem reservas dos Termos e Condições de Uso destas Bibliotecas Digitais, disponíveis em https://digitalis.uc.pt/pt-pt/termos.

Conforme exposto nos referidos Termos e Condições de Uso, o descarregamento de títulos de acesso restrito requer uma licença válida de autorização devendo o utilizador aceder ao(s) documento(s) a partir de um endereço de IP da instituição detentora da supramencionada licença.

Ao utilizador é apenas permitido o descarregamento para uso pessoal, pelo que o emprego do(s) título(s) descarregado(s) para outro fim, designadamente comercial, carece de autorização do respetivo autor ou editor da obra.

Na medida em que todas as obras da UC Digitalis se encontram protegidas pelo Código do Direito de Autor e Direitos Conexos e demais legislação aplicável, toda a cópia, parcial ou total, deste documento, nos casos em que é legalmente admitida, deverá conter ou fazer-se acompanhar por este aviso. 
politica no Brasil do sécu

Categorias aristotélicas por Silvestre Pinheiro Ferreira - Musas errantes: tesouros da Antiguidade Clássica no labirinto da Biblioteca Nacional Brasileira - Eudoro de Sousa e a Mitologia • Câmara Cascudo em defesa de Epicuro - Medéia carioca - Ecos de Platão em Vergílio Ferreira - Imaginário clássico na poesia de António Arnaut - Motivos clássicos na poesia novilatina em Portugal: Manuel da Costa - Uma Ifigénia portuguesa: "Noite escura" de João Canijo • Uma leitura de Mau Tempo no Canal de Vitorino Nemésio $\bullet A$ phýsis grega e o Brasil: as viagens de Von Martius $\bullet$ Fantasia para dois coronéis e uma piscina. Ecos clássicos num contexto do séc. XX

\section{A RECEPÇÃO DOS CLÁSSICOS EM PORTUGAL E NO BRASIL}

Maria de Fátima Silva Maria das Graças de Moraes Augusto COORDENAÇÃo 


\section{SÉRIE MITO E (RE)ESCRITA}

ISSN: $2182-8814$

\section{PERIODICIDADE: Anual}

Apresentação: Poetas, pintores, escultores, na Antiguidade, familiarizados com mitos antigos de deuses e de homens, que cristalizavam experiências, interrogaçóes, respostas quanto à existência do homem no tempo e no mundo, em mitos se inspiraram, em contínua criação-recriaçẩo, para neles verterem a sua própria experiência temporal, com todos os desassossegos e inquietaçóes, com todo o espanto, horror ou encantamento pela excecionalidade da ação humana, que rasga ou ilumina fronteiras de finitude. Esses percursos da criação merecem, hoje, a atenção e análise dos Estudos Literários e, como não podia deixar de ser, dos Estudos Clássicos, muito peculiarmente. Importa, pois, proceder à publicação sistemática de estudos deste cariz, que se destaquem pela qualidade científica e pela originalidade, sendo dedicados, sobretudo, a autores de língua portuguesa. Assim se dá corpo à linha editorial MITO E (RE)ESCRITA.

Este livro, realizado no âmbito do Convénio de Cooperação Académica entre o CECH - Centro de Estudos Clássicos e Humanísticos da UC - e o PRAGMA - Programa de Estudos de Filosofia Antiga da UFRJ -, reúne um conjunto de estudos sobre a recepçáo de temas e modelos greco-latinos na literatura e cultura de Portugal e Brasil.

A sua originalidade resulta da participação de diferentes culturas e das especialidades académicas diversas dos investigadores que nele participam, provenientes da Literatura, da Filosofia e da História Antiga. O lapso de tempo abrangido, que vai do séc. XVI ao XX, permite uma visáo de conjunto da evoluçáo operada no perfil cultural de ambos os países e na definição de um trajeto em boa parte comum. 


\section{Eudoro de Sousa e a Mitologia}

(Eudoro de Sousa and Mythology)

Diogo Ferrer

Universidade de Coimbra

(dferrer@clix.pt) 
Página deixada propositadamente em branco 
Resumo - Eudoro de Sousa, além de receber, estudar e interpretar o pensamento grego no espaço luso-brasileiro, encarna mais do que qualquer outro a recepção luso-brasileira dos clássicos. Mais do que qualquer outro pensador, elevou a recepção do pensamento grego a uma verdadeira assimilação. Os seus estudos não só dão especial atenção à mitologia e à filosofia pré-socrática, como procuram trazê-los a uma nova vida.

Palavras chave - mito, filosofia grega, pré-socráticos.

Abstract - Eudoro de Sousa received, studied and interpreted Greek thought in the luso-brazilian space. In his hands, the reception of Greek culture becomes a true assimilation. His studies not only give special attention to mythology and pre-socratic philosophy, but also try to bring these subjects back to life.

KEYwORDs - myth, Greek philosophy, pre-socratics.

Ao se falar, a partir da filosofia, acerca da recepção dos clássicos em Portugal e no Brasil não se poderia esquecer a figura de Eudoro de Sousa, cujo pensamento, bem mais do que receber, estudar e interpretar o pensamento grego no espaço luso-brasileiro, encarna mais do que qualquer outro a recepção luso-brasileira dos clássicos filosóficos e mitológicos gregos. Por um lado, foi um pensador essencialmente luso-brasileiro, nascido em Lisboa em 1911, formado em Lisboa, na Alemanha e em França, partiu para o Brasil em 1953, onde leccionou nas Universidades de São Paulo, Florianópolis e Brasília, cidade onde faleceu em 1987. O seu pensamento, apresentado em diversos artigos e conferências, encontra-se reexposto de modo extensivo e aprofundado em quatro obras fundamentais: Horizonte e Complementaridade (1975), Sempre o Mesmo acerca do Mesmo (1978), Mitologia (1980) e História e Mito (1981). ${ }^{1}$ Por outro lado, trazendo para a leitura e estudo filologicamente informados da filosofia grega e da mitologia uma linha de pensamento que passa, entre outros, por José Marinho, Eudoro de Sousa elevou a recepção do pensamento grego a uma verdadeira assimilação. Os seus estudos não só dão especial atenção à mitologia $\mathrm{e}$ à filosofia pré-socrática, como procuram trazê-las a uma nova vida. No Prefácio ao seu livro Mitologia, publicado inicialmente em 1980, lê-se que

1 Encontram-se reeditados em Eudoro de Sousa 2002 e 2004. Veja-se também, com diversos estudos sobre o tema, Eudoro de Sousa 2004b. Acerca do pensamento de Eudoro de Sousa poderiam destacar-se os seguintes estudos: Fernando Bastos 1992; E. A. de Soveral 2007, com informação biobibliográfica; Luís Lóia 2007; Fernando Bastos 2001; Dalila P. da Costa 2001; Paulo Borges 2002. 
"embora o livro se refira a mitos, clássicos ou náo", "o autor encara o conteúdo de seu livro como sendo, ele próprio, mitologia." 2

Esta compreensão do que deve ser a leitura e a interpretação dos mitos e do pensamento clássico ou também, para o caso, pré-clássico, é a marca filosófica do autor, que transformou a recepção do pensamento clássico numa filosofia original sobre a relação entre logos e mito, sobre o simbólico, o homem, a sua condição no mundo, a história, o Deus cristão e os deuses. Para Eudoro de Sousa, o pensamento filosófico é essencialmente recuperação da antiguidade e, nomeadamente, dos gregos.

Esta definição central da recepção dos clássicos permite-lhe, nos seus termos, "desengonçar", isto é, tirar dos gonzos onde gira, a generalidade do pensamento filosófico e da concepção do mundo ocidentais. A Grécia antiga não é um episódio na história do pensamento, mas o limite e limiar onde algo de decisivo para a compreensão do homem acontece. Com o pensamento pré-socrático e com a passagem a Platão, define-se a possibilidade de um novo tipo de concepçáo do passado e do presente, até então desconhecidos. Eudoro considera a história como uma sucessão de épocas, sem progresso ou regresso, ${ }^{3}$ que representam diferentes manifestaçóes da cultura.

Pode compreender-se a sua definição de cultura a partir do seguinte passo:

"o Projecto instituidor de homem e mundo (entrelaçados simbolicamente, se no entrelaçamento também se enlaça o Projecto, ou se referência de um a outro se faz só por referência de um e outro ao mesmo Projecto), possa ou náo possa ele passar por nós com o nome de Cultura - Cultura envolvida e ocultada por suas manifestaçóes, tal como homem e mundo envolvem e ocultam o Projecto que os instaura -, é abertura por onde irrompe um impensado vindo à presença de todo o pensar que se encontra em regime de disponibilidade." ${ }^{\text {”4 }}$

Para começar a ler Eudoro, deve registar-se desde logo que, de uma maneira que evoca fortemente o pensamento pré-socrático, cada passo do seu texto apela à interpretaçáo, a qual deve passar pela reflexão acerca de cada termo fundamental, muitas vezes grafado com maiúscula, e empregue de um modo que causa normalmente estranheza. Cada frase do autor

\footnotetext{
2 Eudoro de Sousa 2004: 21.

3 Cf. Eudoro de Sousa 2004: 235.

4 Eudoro de Sousa 2004: 32.
} 
constitui um discurso similar ao pré-socrático, onde um fragmento é fonte de inesgotável leitura e interpretação. A estranheza do uso dos termos no contexto em que Eudoro os emprega deriva de uma semântica que nos aparece, tomando em atenção as definiçóes e as concepçóes gerais do autor, como totalmente interior ao seu sistema de significaçōes.

Antes de passar à exposição do que o autor entende por mito e símbolo, deverá contudo começar-se pela compreensão do que compreende como horizonte e complementaridade, e qual a importância destes conceitos para a interpretação do humano e do mundo hoje - e sempre - na sequência do pensamento grego.

Eudoro parte da perda e do esquecimento actuais do horizonte resultantes "de mais de vinte séculos de reflexão filosófica e de investigação científica," que vieram a fazer esquecer a sua vivência originária. Filosoficamente, o horizonte é a definição fenomenológica por excelência de uma lei fundamental da determinação consciente, segundo a qual a condiçáo principal de que se veja algo de modo definido, ou seja, de o focar tematicamente, é a sua circundação por uma indeterminação não temática designada como horizonte. Este é o halo indefinido que institui o mundo focal da consciência, instituição que tem como exemplo privilegiado o tempo, em que o presente se define necessariamente como a intensidade do vivido, em oposição às modalidades menos definidas do passado e do futuro. E, por outro lado, o horizonte náo é uma linha objectiva, real, em sentido semelhante à que define os objectos iluminados dentro dele, mas um limite que é tanto do mundo quanto do nosso próprio olhar sobre o mundo. O horizonte é, assim, a própria correspondência da nossa visão e do nosso saber com o mundo objectivo.

Dois pontos centrais se podem realçar acerca desta concepção do horizonte. Por um lado, esta lei do horizonte diz-nos que todo o definido nasce a partir de um indeterminado. Por outro, insere todo o conhecimento temático num limite, que não é ocasional, mas constitutivo. Sem horizonte limitador e sem nocturno "além-horizonte", não há, nos termos de Eudoro de Sousa, tăo-pouco algum "aquém-horizonte" visível e diurno. Estas duas consequências do horizonte, o facto de que há um nascer, uma passagem a partir da obscuridade para as formas definidas do mundo habitável, e de que todo o saber é limitado, são ideias centrais no pensamento do autor sendo na verdade náo mais do que dois aspectos de uma mesma concepçáo do mundo e do homem.

\footnotetext{
5 Eudoro de Sousa 2002: 31
} 
A perda do horizonte é o que se iniciou desde os alvores do pensamento ocidental e significa, assim, que o saber simultaneamente perdeu todos os seus limites e deixou de se conceber como originado a partir do seu oposto, ou seja, que há algo que o antecede fundamentalmente. Isto que o antecede é, como se verá, o próprio mito e o símbolo como origem da significação que permitia constantemente religar aquilo que o horizonte separa, nomeadamente, o céu e a terra. E o horizonte é símbolo porque é a linha de junção entre céu e terra, entre o obscuro e o descoberto, é a limitação e a sua transposição, limes e limen. Esta transposição é a fonte primeira do símbolo e do significado no mito e, posto que o mito é historicamente o primeiro, também na história. A diferença entre o pensamento histórico que só tem presente, e o pensamento mítico, que é essencialmente passado, no que novamente história e mito coincidem, é acerca do modo como o passado é actual. Para Eudoro, a presença do passado é constitutiva, assim como o irracional é o alimento do racional. Este processo de criação do tempo encontra-se já numa das principais influências de Eudoro de Sousa tanto no que toca às concepçóes sobre a mitologia quanto sobre o tempo, a saber, Schelling. Para este

"o homem que não se superou não tem passado, ou, antes pelo contrário, não sai jamais do passado, vive constantemente nele. [...] Só o homem que tem a força de se arrancar de si mesmo [...] é capaz de criar para si um passado; e esse, justamente, desfruta também de um verdadeiro presente, e está propriamente perante um futuro." ${ }^{\prime 6}$

Este acontecimento criador do passado e do presente será representado, como veremos mais abaixo na análise da obra de Eudoro, por um acto de violência, que é tanto violência sobre si como sobre o si-mesmo que tem de passar a ser outro, a natureza.

Mas todo o saber filosófico, artístico, religioso e mítico depende da transposição do horizonte, de tal modo que, segundo Eudoro,

"desde a primeira transposição mítica até à derradeira transposição
metafísica da incógnita e talvez incognoscível vivência que situamos
no início da história e no limiar da consciência, o fascinante mistério
do horizonte sempre se nos revela em sua enorme espessura existencial."

6 W. F. J. Schelling 1968: 65. Acerca do próprio mito já como o limiar crítico da consciência filosófica, veja-se Schelling 1957: 20.

7 Eudoro de Sousa 2002: 33. 
O autor procura fundamentar a tese de que a origem do sentido está na conjunção e disjunção do horizonte pela pesquisa no corpus mítico da antiguidade grega, encontrando confirmaçóes desde Homero até ao pensamento platónico. De Homero, são as seguintes caracterizações: "parto a ver os limites da terra nutriz, o Oceano, génese dos deuses"; ou a referência ao "Oceano, que na verdade é génese de todas as coisas." Assim, conclui Eudoro, do horizonte-Oceano provêm os próprios deuses e todas as coisas, e o extremo é também o primordial no processo "teocosmogónico".

Mitologicamente, o horizonte remete para a separação entre Céu e Terra, que se encontra universalmente codificado na mitografia, sendo documentável em todo o mundo "- tribos africanas, Egipto antigo, Grécia moderna, literatura babilónica e judaica, Hurritas e Fenícios, na Índia, Sibéria, Ásia oriental," etc. ${ }^{9}$ Numa composição de espaço e tempo, antes e além do horizonte e, de certo modo, também ainda hoje, todas as noites, desde a sua separação e o sugimento da luz, Terra e Céu, vigília e sono são uma só e a mesma figura ainda indistinta.

Assim, além deste limite-origem está a indiferença entre Céu e Terra e, consequentemente, também da vida e da morte, "numa complementaridade que misteriosamente se oculta por detrás do horizonte." ${ }^{10}$ A filosofia pré-socrática dos fisiólogos vai codificar este horizonte, como arché e como o Indiferenciado, segundo Anaximandro. Mas é esta identidade do fenómeno nas suas duas codificaçóes que conduz o autor à tese do que denomina a "complementaridade" que, pela primeira vez, se atesta na relação entre o mito e o logos.

Segundo Eudoro, esta relação e passagem entre mito e o logos é, antes, uma permanente complementaridade, onde não há sucessão, mas duas codificaçóes distintas de uma mesma incógnita. Para lá do horizonte de visibilidade, vêm ao nosso encontro dois modos de grafar uma mesma vivência e uma mesma questão. Na complementaridade de Eudoro poderia encontrar-se também a tese adorniana, que vê num jogo de transformação especular, no mito já esclarecimento, e neste ainda o mito.

A tese de Eudoro acerca do surgimento da filosofia é que "a physis dos pré-socráticos nasceu subitamente como que do 'interiorizar-se', do 'recolher-se', do 'encerrar-se' de uma natureza que antes náo tinha dentro nem fora. [...] A natureza não teve dentro nem fora até ao dia em que alguma de suas

\footnotetext{
8 Ilíada, 14, 246, 302, cit. in Eudoro de Sousa 2002: 33, 34.

9 Segundo Staudacher 1942, cit. in Eudoro de Sousa 2002: 53.

10 Eudoro de Sousa 2002: 48.
} 
partes, algum dos seus membros, separando-se dela, ficou de fora." ${ }^{\prime 11}$ Esta parte e membro que ficou no exterior da natureza, a qual passou por isso a ter "fora" é, evidentemente, o homem. Por um lado, encontra-se aqui uma complementaridade pela qual a filosofia da mitologia não pode ser feita sem uma correspondente filosofia da natureza - no que Eudoro mais uma vez faz referência explícita a Schelling. Mas este processo de emergência do logos não se deterá numa natureza ainda povoada de deuses, e não descansará enquanto não os expulsar da sua morada na natureza e, assim, acabar por desfazer todo o sentido dos símbolos. Esta perda de sentido tem um primeiro momento na alegorização do símbolo evidenciada na catábase e vivência do horizonte na caverna de Platáo. O peculiar desta alegoria-mito platónica é que, ao contrário do que acontecia na codificação mítica, a instituição do "para lá do horizonte" provoca a degradação de todo o sensível situado "para cá do horizonte". Na codificação mítica o além do sensível não faz degradar o sensível, o que só acontece a partir de Platáo. ${ }^{12}$ Este é um primeiro passo no caminho da separaçáo do cosmos num mundo sem deuses e em deuses sem mundo, que irá culminar no mito do Homem, a priori de toda a cultura actual, e tanto mais fundamentalmente mito quanto menos se reconhece como tal.

Mas retornemos à caracterização do pensamento de Eudoro de Sousa pelo próprio autor, que pretende ultrapassar esta cisão instaurada desde Platão. O seu texto e pensamento, como começámos por referir, reivindicam para si o estatuto de mitológicos, na medida em que a mitologia deve ser concebida justamente como um aparente encerramento do discurso na lógica imanente das suas próprias definiçóes fundadoras. Eudoro recusa uma interpretação alegórica dos mitos, porquanto os mitos náo querem dizer outra coisa do que aquilo que dizem, tão pouco quanto a obra de arte ou os símbolos em geral podem ser interpretados desse modo alegórico. Não há que decifrar lá onde nunca se cifrou. $\mathrm{O}$ mito não deve ser explicado por traduçấo noutra coisa que significasse. Não faz sentido perguntar pelo significado de um mito

\footnotetext{
“a não ser que [...] a pergunta 'Que significa...?' se refira à significação que o mito confere, e não à que lhe é conferida. Quanto a mim, estou convencido de que um mito confere significação e que nada existe que lha confira a ele."13
}

\footnotetext{
11 Eudoro de Sousa 2002: 194.

12 Cf. Eudoro de Sousa 2002: 121-122.

13 Eudoro de Sousa 2004: 44.
} 
O mito dá significação "de dentro de si" ${ }^{14}$ e não a pode receber de fora. É verdade que, como origem de significação, ele pode dar voz a forças, fenómenos, "situaçóes-limite como o nascimento e a morte, as metamorfoses do homem", ${ }^{15}$ e outros dos dramas humanos no mundo. Mas a alegorização está, quanto à fonte da significação, sempre a jusante, a potência pertence primeiramente ao mito. $\mathrm{O}$ autor lembra, no entanto, que quase dois milénios de alegorização não podem ter sido em vão, razão por que a alegoria deve conter alguma verdade: a sua verdade não é que o mito deva dizer outra coisa senão o que diz, mas é a de fazer recordar que o mito não pode ser entendido separadamente do mundo e do drama que nele acontece, que o mito remete sempre para o mundo. O principal problema da alegoria é que não se recorre a ela para também "alegorizar o mundo", ${ }^{16}$ que fica então preso na sua "tautegoria" - ao passo que a função do mito é justamente a de alegorizar o mundo. A "abertura" e "disponibilidade" acima referidas seriam esta possibilidade de também alegorizar o mundo e encontrar a presença nele do impensado.

Para Eudoro, o pensamento dotado do que chama "disponibilidade" é precisamente um pensamento assim, na aparência fechado dentro das suas definiçôes fundadoras, que caberia ao leitor reabrir. Isto significa, por um lado, que o mito é cosmopoético. Não é, por isso, verdade, que cada entidade mitológica, um deus, por exemplo, manifestaria ou encarnaria um aspecto do mundo, força ou potência nele presente. ${ }^{17}$ Esta formulação não é admissível na medida em que ser "aspecto do mundo" faz do mito não mais do que, por assim dizer, um acidente de um mundo substancial, que se divide em aspectos ou modos. Segundo esta concepção que Eudoro critica, "a consistência é a do mundo", ${ }^{18}$ não a do deus, o que não está de acordo com o sentido da narrativa mitológica. Eudoro insiste em que esta narrativa é incompatível com a fundamental crença no mundo, como substância de que dependeriam estes supostos "aspectos". Assim sendo, acerca dos deuses e da sua relação com o mundo "melhor se diria: 'um deus é um mundo' e 'outro deus é outro mundo', em suma, cada deus munda, faz seu mundo do que ainda não o era - diacosmiza, numa palavra só." ${ }^{19} \mathrm{O}$ discurso mitológico é

\footnotetext{
14 Eudoro de Sousa 2004: 45.

15 Eudoro de Sousa 2004: 45.

16 Eudoro de Sousa 2004: 47.

17 Eudoro de Sousa 2004: 41.

18 Eudoro de Sousa 2004: 42.

19 Eudoro de Sousa 2004: 42.
} 
"diacósmico", tem a forma da "tautegoria" e aparece como auto-significante, porque conter-se a si mesmo no seu significado é característica própria do que chamamos um mundo. E assim, só pode ter a capacidade de aceder ao fundamental da racionalidade, do homem e do discurso, o pensamento que se dispóe como mitologia.

No entanto, deve-se, por outro lado, atender à própria noção referida de "regime de disponibilidade", a qual faz apelo a uma outra condição do discurso mitológico, que não a do seu encerramento semântico. O discurso simbólico não é de modo nenhum fechado no sentido de concluso, o que implica que a aparência de encerramento em si mesmo do discurso filosófico-mitológico é somente uma aparência. Pelo contrário, como a frase inicialmente citada nos adverte, "o Projecto instituidor de homem e mundo" é caracterizado pela "abertura" e pela "disponibilidade". A contradição desaparece na medida em que se admitir que o encerramento do discurso sobre si mesmo é o que permite que ele aponte para a sua fonte de significado, ou para o significado em geral do discurso. Pelo contrário, o discurso que Eudoro caracteriza de objectivador, próprio do logos raciocinante, é aquele cuja abertura se dá unicamente em direcção a objectos e a um mundo cujo horizonte de sentido é não só concluso, mas desconhecido de si mesmo como horizonte. Trata-se, no mito do pensamento pós-mítico, de ocultar a ocultação, pelo que o oculto é devolvido na crueza mais integral do poder fáctico impensado, que Eudoro encontra no mundo hodierno "diabólico" (justamente porque não "simbólico") dos objectos.

Eudoro insiste na diferença entre limite e limiar, limes e limen. O limiar é a disponibilidade aberta. Sem o conhecimento do horizonte não há sentido humano do discurso e, posto que todo o sentido e todo o discurso tem pelo menos um dos seus vértices no humano, sem o conhecimento do horizonte não há sentido do discurso. Assim, o sentido de todas as significaçóes é originalmente mitológico e por isso, o discurso filosófico que pretenda iluminar o horizonte de sentido é um discurso cuja estranheza apenas reflecte o facto de que o autor quer - mais do que comunicar, ensinar ou transmitir ideias - despertar.

O despertar é o tema do longo confronto que o autor apresenta, em Horizonte e Complementaridade, com o Fragmento 1 de Heraclito. Aqui se lê, na traduçáo de Eudoro, que

“este logos, sendo (como o enuncio), sempre o não entendem os homens, quer antes de o haverem escutado, quer após o terem ouvido. Pois, ainda que tudo suceda em conformidade com este logos, inexpertos parecem, mesmo que experimentem palavras e acçóes, tal como eu as exponho, distinguindo a natureza de cada uma delas e explicando-a 
tal qual é. Os demais homens, porém, táo pouco sabem o que fazem despertos, quão pouco se lembram de que fizeram dormindo." ${ }^{20}$

Despertar para o horizonte e o seu significado como limiar é o que o autor designa como a "transcendentização do horizonte próximo," ${ }^{21}$ ou também aceder à "trans-objectividade". Esta trans-objectividade significa "desencantar" os objectos mundanos, ir além da fixação definitória dos objectos até ao seu horizonte de sentido que, segundo Eudoro, é o horizonte do que denomina o "impensado". Aqui novamente reencontramos o topos adorniano de um esclarecimento que prossegue com o encantamento mítico do mundo, e cuja principal caracteristica de falsidade é a do mito que se mantém como poder actuante, mas não se enxerga.

Retomando a nossa questão inicial sobre aquilo que na Grécia antiga ocorreu de decisivo para a compreensáo do humano, recordamos que se tratava, para Eudoro, de compreender a história como sucessão de épocas sem progresso nem regressão. A história está submetida, vimos, ao "Projecto instituidor de homem e mundo". Note-se que o autor não refere a cultura a um projecto, mas ao Projecto, que parece designar em geral a instituição de homem e mundo segundo a referida exteriorização da natureza. Esta instituição é um processo que não é propriamente histórico, mas fonte de sentido de toda a história, o passado que acompanha o presente como a diferença que institui as épocas do tempo. Estas, especialmente o passado e o presente, não são entendidas como uma sequência linear simples, mas como um "projecto" que rege todo o acontecimento histórico. O tempo não é um simples movimento unidireccional, como numa linha que se prolonga indefinidamente, mas um complexo de estratos de significado diversificado.

O tempo começa, segundo Eudoro de Sousa, pela criação de um passado, que é mítico e, afinal, identifica-se com a própria natureza. Sempre na base do racional encontra-se o irracional. "A racionalização que por muito alongada para trás e para a frente de qualquer aqui e agora se pense sempre parte de um irracionalizado e sempre em um irracionalizado se detém." 22 A própria origem da história e da temporalidade se pode encontrar nesta criação de passado que, como horizonte, é o passado sempre presente da natureza, da sensibilidade e da mitologia. A mitologia não é, por conseguinte, nem alegoria, nem o representante de um estádio passado, ainda não esclarecido, da humanidade,

\footnotetext{
20 Eudoro de Sousa 2002: 130.

21 Eudoro de Sousa 2002: 132.

22 Eudoro de Sousa 2004: 37.
} 
mas a fonte sempre presente da correlação entre homem e mundo. $\mathrm{O}$ mito não é princípio, mas origem sempre presente de onde se alimenta a razão.

A instauração de homem e mundo acontece pelo culto ou pela dança, os quais, segundo Eudoro de Sousa, estáo na origem de toda a cultura e de todo o símbolo, mitológico ou outro. O projecto é o horizonte de possibilidades de sentido ou, segundo a terminologia do autor, "de um Drama que póe em movimento a acção de que o homem julga ter a iniciativa; o Projecto abre um leque de limitado número de possibilidades para lances (que nunca são originais) no jogo que o homem joga com o mundo e consigo mesmo." ${ }^{23}$ $\mathrm{O}$ jogo de sentido instaurador do mundo é simultaneamente, afirma o autor, a ocultação do projecto que está na sua base.

A tese da ocultação e do desvelamento do sentido no mito provém da concepção religiosa do mito fundamental que, segundo Eudoro, é o mito da origem. Eudoro busca encontrar o motivo do ocultar e desocultar de sentido do mito e de toda a linguagem simbólica no mito primordial pré-helénico da origem, segundo o qual o mito não é biografia dos deuses, mas thanatografia, narrativa da morte do deus como condição da posição do mundo e do homem mortal. O mundo e, com ele, todo o símbolo em geral é definido como "cosmofania teocríptica", que se vai estender até à palavra de Nietzche e Dostoiewski - mas primeiramente, antes destes, acrescente-se, de Hegel, - de que "Deus morreu". ${ }^{24}$ A origem do homem é o deicídio, já desde a mitologia aparentemente universal dos "Dema-Gottheiten (divindades-dema)" próprios dos povos sedentarizados pela agricultura.

Como exemplificativo desta tese, Eudoro apresenta o mito da ilha de Ceram, junto à Nova Guiné, narrado por Adolph Jensen. Segundo este mito, os homens eram originariamente deuses que, ao colaborarem num deicídio, permitiram a criação do mundo humano:

\footnotetext{
"outrora [...] deuses-homens dançavam uma dança que se prolongava por nove noites consecutivas [...], e ao fim da nona, em que finalizava a dança, os dançarinos que se dispunham em fila espiralóide, violentamente calcaram para dentro da terra uma moça que, no centro da espiral, e sem participar da dança, por todos distribuíra, noite após noite, bens cada vez mais preciosos. Na manhã seguinte, o pai, espantado pela ausência da filha, pôs-se em busca dela, e lá a encontrou moribunda, sob a terra, no centro do terreiro. A moça, que se chamava Hainuwele, ainda teve tempo de prescrever o destino do seu cadáver: que fosse cortado em
}

\footnotetext{
23 Eudoro de Sousa 2004: 42.

24 Cf. Eudoro de Sousa 2004: 49, 50.
} 
pedaços e esses fossem enterrados em volta do terreiro em que se celebrara a dança. Passado algum tempo, nos lugares em que tinham sido sepultados os pedaços do corpo de Hainuwele, nasciam, pela primeira vez, as plantas tuberosas de que se alimentam os homens da regiâo." ${ }^{25}$

Deuses comparáveis são Dioniso, Osíris, Átis, Deméter ou Perséfone. E, do mesmo modo, na narrativa babilónica de Gilgamesh encontra-se o mito da criação segundo o qual Marduk fez o mundo dividindo o cadáver de Tiamat, sendo por outro lado também a mutilação de Úrano por Crono na Teogonia de Hesíodo entendidos como equivalente à morte. $\mathrm{O}$ mesmo mito da origem pela morte do deus estaria presente ainda nas religióes "mistéricas" da antiguidade e constituiria o conteúdo afinal do próprio cristianismo. Com efeito, a morte de deus seria o motivo da mediação possível entre o mundo e os homens, por um lado, e os deuses, por outro, estando então na origem de toda a simbolizaçáo.

O mito cria o mundo não só no sentido da sua separação em relação ao homem e ao divino, mas também como segregação do passado que, viu-se, é instituído pelo mito. Este remete não para um passado mundano ou definível relativamente ao presente, mas a um outrora antes do mundo e dos homens como homens. Nos termos de Eudoro, "o Mito é a expressão da presença do passado, como a História é expressão da presença do presente", ou seja, é o que antecede toda a possibilidade de uma interpretação alegórica, que o autor define como "a transposição mortificante da sensibilidade para a inteligibilidade." ${ }^{26} \mathrm{~A}$ natureza, o sensível, o irracional são o passado de uma inteligibilidade que é presente histórico e mundo. $\mathrm{O}$ olhar do logos é sempre retrospectivo em direcção a uma unidade que já se diferenciou, e a irreversibilidade do passado é constitutiva do nosso próprio olhar distanciado da sensibilidade e da natureza. Por isso, o deicídio original tem também de ser a destruição da natureza como condição da construção do mundo humano histórico, mundo de onde se perdeu a perspectiva simbólica, substituída pela tautegoria do mundo que é o mito como alegoria.

Todo o símbolo, segundo Eudoro, é "triangular" correspondendo a uma ligação indissociável entre homem e mundo, na base do triângulo, e um deus no vértice. A tese de Eudoro acerca do projecto pelo qual se desenvolveu a história e a relação entre coisas e símbolos, que permite entender o desenvolvimento do pensamento a partir da Grécia antiga, é que o vértice

\footnotetext{
25 Eudoro de Sousa 2004: 81.

26 Eudoro de Sousa 2004: 348.
} 
do triângulo desapareceu como "aceno" do divino, tendo os dois lados colapsado numa simples linha de que está ausente toda a verticalidade.

Sem que se possa agora explorar mais além o valioso diagnóstico que Eudoro de Sousa faz do homem contemporâneo, imerso no mito sem mito dos objetos encantados, refira-se apenas que a principal ameaça ao seu sentido é a desintegração do simbólico. Esta destruição do simbólico é vista por Eudoro, por um lado, a partir da oposição entre símbolo e coisa e, por outro, com base na oposição entre 'simbólico' e 'diabólico'. A primeira oposição é remetida para uma diferença entre a "desintegração do símbolo" que unicamente constitui a coisa, e a "reintegração da coisa" que constitui o símbolo e a restitui a um mundo habitável. Assim, as "coisas são pedaços dispersos de símbolos diabolicamente destruídos. ${ }^{27} \mathrm{O}$ diabólico das coisas é o crítico e separador que não desencanta propriamente o mundo, como se referiu, mas, pelo contrário, que o encanta $\mathrm{e}$ faz perder o seu sentido num mundo "fragmentado em 'coisas' separadas." ${ }^{8}$

E porque o discurso simbólico e mitológico não admite encerramento ou conclusão, permito-me concluir com uma citação acerca das "coisas-só-coisas" que resultam da sua desintegraçáo "diabólica" resultante do achatamento do triângulo simbólico:

\begin{abstract}
“as 'coisas-só-coisas' não se nos apresentam e não se representam senão por virtude do libreto que o Diabo escreveu, e a 'peça que ele nos pregou' foi a de nos fazer acreditar que seja essa a única que os homens [...] desempenham no Mundo [...] que ele negativamente criou. Agora já sabemos o que significa esse 'negativamente': é a negação do simbólico; por afirmaçáo persistente e insistente de que o Homem pode e deve recusar-se a ver na coisa que ele é, e na coisa que é o Mundo, mais do que a deliberada tendência de um a outro se ligarem por vínculos que, sendo apenas externos, facilmente se quebram ao sabor do nosso soberano arbítrio."${ }^{29}$
\end{abstract}

A recepção dos clássicos permite pois a Eudoro de Sousa uma reconstrução de todo o percurso da história ou do "projecto" desde o mais antigo mito da origem, ou mesmo mais atrás, no culto e dança pré-simbólica ainda até ao arbítrio soberano de um mundo composto por coisas sem efectivo vínculo a coisa alguma, onde, no seu diagnóstico, se situa um homem desintegrado, como só mais uma coisa.

\footnotetext{
27 Eudoro de Sousa 2004: 107.

28 Eudoro de Sousa 2004: 124.

29 Eudoro de Sousa 2004: 111.
} 


\section{Eudoro de Sousa e a Mitologia}

\section{Bibliografia}

Bastos, F. (1992), Mitologia e Filosofia: Eudoro de Sousa e a complementaridade do Horizonte. Brasília: Editora da Universidade.

Bastos, F. (2001), "As Posiçôes Filosóficas de Eudoro de Sousa", in Mito e Cultura: Vicente Ferreira da Silva e Eudoro de Sousa. Lisboa: Instituto de Filosofia Luso-Brasileira: 113122.

Borges, P. (2002), "Do perene regresso da filosofia à caverna da dança e do drama iniciático. Rito e mito em Vicente Ferreira da Silva e Eudoro de Sousa”, in Pensamento Atlântico. Lisboa: INCM: 413-425.

Costa, D. P. (2001), "Horizonte e complementaridade em Eudoro de Sousa", in Mito e Cultura: Vicente Ferreira da Silva e Eudoro de Sousa. Lisboa: Instituto de Filosofia LusoBrasileira: 133-144.

Lóia, L. (2007), O essencial sobre Eudoro de Sousa. Lisboa: INCM.

Schelling, W. F. J. (1957), Einleitung in der Philosophie der Mythologie. Darmstadt: WBG.

Schelling, W. F. J. (1968), Die Weltalter, in Schriften von 1813-1830. Darmstadt: WBG.

Sousa, E. de (2002), Horizonte e Complementaridade: Sempre o mesmo acerca do mesmo. Lisboa: INCM.

Sousa, E. de (2004), Mitologia, História e Mito. Lisboa: INCM.

Sousa, E. de (2004b), Dionisio em Creta e outros Ensaios. Lisboa: INCM.

Soveral, E. A. (2007), "Eudoro de Sousa” in Calafate, P. (Dir.), História do Pensamento Filosófico Português: O século XX. Tomo I. Lisboa: Círculo de Leitores: 297-315.

Staudacher, W. (1942), Die Trennung von Himmel und Erde. Eine vorgrieschicher Schöpfungsmythus bei Hesiod und die Orphikern. Tübingen: Bölzle. 
Maria de Fátima Sousa e Silva é Professora Catedrática do Instituto de Estudos Clássicos da Universidade de Coimbra. Desenvolveu, como tese de doutoramento, um estudo sobre a Comédia Grega Antiga (Crítica do teatro na Comédia Grega Antiga), e, desde então, tem prosseguido com investigação nessa área. Publicou já traduções comentadas de nove comédias de Aristófanes, além de um volume com a tradução das peças e dos fragmentos mais significativos de Menandro.

Maria das Graças de Moraes Augusto é Professora Titular no Departamento de Filosofia do Instituto de Filosofia e de Ciências Sociais da Universidade Federal do Rio de Janeiro (UFRJ). A sua investigação sobre História da Filosofia Antiga abrange temas como Platão e a herança platónica, filosofia e conhecimento no pensamento antigo, filosofia e literatura na tradição antiga e recepção dos clássicos gregos no Brasil.

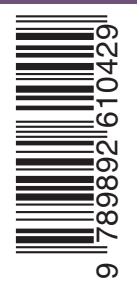


OBRA PUBLICADA

COM A COORDENAÇĀO

CIENTÍFICA
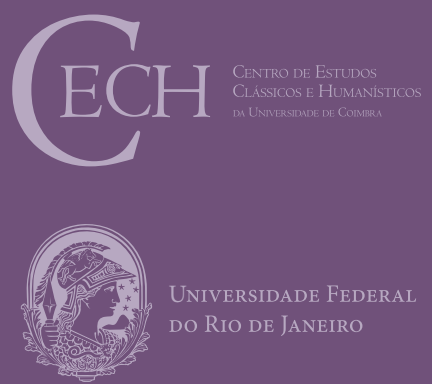

- U 